\title{
THE EFFECT OF WIND ON THE VEGETATION OF THE DUMBARA HILLS (KNUCKLES RANGE)
}

\author{
${ }^{1}$ WMGB Giragama and ${ }^{2} \mathrm{~S} N$ Wickramarathne \\ ${ }^{1}$ Hector Kobbekaduwa Agrarian Research and Training Institute. Colombo 07 \\ ${ }^{2}$ Department of Geography, University of Peradeniya, Peradeniya
}

The Dumbara Hills are in the Kandy and Matale districts. They straddle between $7^{\circ} 18^{\prime}$ and $7^{\circ}$ $34^{\prime} \mathrm{N}$ and $80^{\circ} 41^{\prime}$ and $80^{\circ} 55^{\prime} \mathrm{E}$, covering some 28,000 ha. The range extends along a NW-SE axis for about $20 \mathrm{~km}$. This massif, gradually rising over the NE of Kandy plateau slopes precipitously to the eastern Dry Zone plain. There several high peaks in the Dumbara Hills, Gombaniya (1904m) Knuckles (1863m) and Dotalugala (1574m).

Dumbara Hills make an impregnable barrier to tre NE and SW monsoon rains and are characterized with four major forest formations, nemely; Lowland Dry Semi-Evergreen, MidElevational Wet Evergreen, Mid-Elevational Dry Evergreen and Montane Wet Evergreen Forests or cloud forests.

Deformed trees develop under the influence of severe environmental factors. The 'pigmy forest' and wind-shaped trees in other parts of the range are examples of theses. In such habitats the trees are stunted (stature 1-2 m) despite that they ara hundreds of years old. Moreover, they are gnarled and twisted. The barks are covered with lichars and mosses, and support many epiphytic ferns as well as angiosperms. Wind shaped trees abundant on peaks of the Dumbara Hills are useful indicators to study dendrological effects of wixis.

This study was done by visual observation of wini-shaped trees in the field to estimate the dominant wind direction. The wind conditions were in ferred by observing the wind shaped-trees in and around the Dumbara Hills. Considering the position of the wind-shaped trees, mean wind velocity was estimated based on the ranks mentioned by the following equation.

$\mathrm{WS}=1.6+0.95 \mathrm{GSL}$ WS is the mean wind velociy $(\mathrm{m} / \mathrm{sec})$ observed at the meteorological station in summer. GSL is the grade of wind-shaped tees.

The observations were made at fourteen points in the Jumbara Hills and, outside in the vicinity. In then sample were silver oak (Grevillea robusta) and gum (Eucalyptus sp.) trees. There are three locations identified with strong winds; Lakegala, Asgirikanda and Ovilikanda. Asgirikanda and Ovilikanda are a few $\mathrm{km}$ north of the range and Lakegala is on the east. In the first two locations are NW winds and in the third are SW wirds.

The second area includes Bambarella on the western slope (middle) of the range with SW winds, Looloowatta, on the eastern on the eastern slope of the range with NNE winds and Hunnasgiriya, in the southern end of the range, with winds from SW direction.

The third area is Kirimetiyakanda near the northern erd of the range, where the prevailing winds are from SSW and Katuattamada, on the western slope range where there are winds from SW direction. Wind-shaped trees are rarely found in the eastern lowlands (Wilgamuwa) northeast of the range. Hence it was not possible to continue streamlines up to the eastern low lands. 